\title{
Response to "Relations between Archaeologists and the Military in the Case of Iraq"
}

\author{
Jon Price \\ Northumbria University \\ No Man's Land \\ WAC Council and Executive
}

My response to this paper is informed by my knowledge and the context to that knowledge. It is not intended as an ad hominem response, but statements in John's paper are instead taken to stand for and represent similar statements by other commentators made elsewhere.

I am an archaeologist. A long time ago, I studied the Sassanian dynasty of Persia (modern Iran), under Dr Bivar at the School of Oriental and African Studies. The opportunity for fieldwork never arose for socio-political reasons. For a number of years, I have worked closely with serving military personnel, dealing with military archaeology, (the archaeology of military sites and personnel) in Britain, Belgium and France, and with Ministry of Defence (MoD) archaeologists who work with the military on training ranges in Britain. I was actively involved in political debate prior to the invasion of Iraq, being at the time a Labour party officer in the constituency of a cabinet minister. I was then, and remain now, opposed to the invasion of Iraq, in itself and as part of the 'War on Terror'. I organised a session at the 2008 World Archaeological Congress (WAC) in Dublin entitled "Working with the Military: Not Evil, Just Necessary" which contained papers by US and Dutch military archaeologists, UK MoD personnel, a lawyer, and myself. This session ran despite massive opposition from those elements within WAC who refuse any dialog with the military. It also had the dubious privilege of close police protection after the police received "credible threats of disruption" (pers. comm. C. Smith).

The British military is a legitimate arm of a western capitalist state. If we are to take a moral stance on working with the military we must also do the same in relation to the police (forensic work), the education system, and ultimately any source of funding derived from capitalist organisations rather than from open public collection. The fact that we do not is an indication of pragmatism. There are archaeologists who refuse/oppose all these things, though largely they remain employed by and within the education system.

If we are to single out the military for our boycott, then we should apply that boycott at all locations where archaeology and the army intersect. All army training ranges were used in the preparation for the invasion of Iraq, and they support the continued occupation. A refusal to work with the army in Iraq should be accompanied, inter alia, by a refusal to work with them on Salisbury Plain, and on the Otterburn ranges in Northum

Papers from the Institute of Archaeology 19 (2009): 9-11 
berland. Both of these locations contain significant remains of human activity, which are essential to an understanding of our national past.

Those archaeologists who would choose to work in Iraq without overt cooperation with the army have difficulty gaining access to sites, as John explains, and so are unable to carry out the archaeological work they set out to do. More critically, visiting archaeologists have to work in close cooperation with mercenary organisations. John specifically mentions Pilgrim Elite, and Control Risks Group. Mercenaries are military organisations operating outside the checks and balances applied to the state military. They are implicated in significant contraventions of ethical, moral and legal norms. Nevertheless this is not addressed as an issue by groups who carry out, or suggest carrying out, work without cooperating with the army. For example, on a personal, moral and ethical level, I would rather be associated with the US Army than with Blackwater USA.

In the film Apocalypse Now (1979), Willard, the Special Forces officer, says, after his crew have massacred the civilian occupants of a boat: "It was a way we had over here of living with ourselves. We'd cut them in half with a machine gun and give 'em a band aid. It was a lie." This principle is similar to archaeologists refusing to cooperate with the military before and during the invasion on the basis of a statement of political, moral, or ethical belief, but then agreeing to go into Iraq to survey and 'rescue' archaeology. The first position claims the moral high ground by refusing to support aggression against the population of Iraq. The second position appears to support the Iraqi people, but in fact is actually driven by an attachment to the archaeology of Iraq. The archaeology is seen as detached and separate from the Iraqi people, who are implicated in its destruction through the construction of defensive works during the war, and its neglect during the long and costly war between Iraq (as a US surrogate), and Iran.

Aside from this the Hague Convention for the Protection of Cultural Property in the Event of Armed Conflict (1954) is clear in stating that States must attempt to minimise damage to cultural heritage during armed conflict. This needs preparation, and archaeologists, as citizens of these States are the logical personnel to engage in this process, unless we consider the Hague Convention to have no relevance.

Archaeologists are implicated in the colonisation of Iraq, as they always have been. The British Museum has national status, is part of the British establishment and is (in the eyes of the colonised) as much an arm of the state as is the army. The simple statement that the Museum has a special interest in Ur because of Woolley's excavations there from 1922 to 1934 has huge implications for colonial attitudes, responses and relationships. The statement "contaminating the record at Babylon" seems innocent except that it isolates the early human activity, and neutralises the cultural heritage of Babylon, by removing this record from association with the surrounding Iraqi population. It also implies that the activities of the invading armies of the 21 st century are somehow different from the activities of invading armies from earlier centuries, and so do not constitute part of that continuum of heritage and history. 
Finally, there is the question of the psychology of cooperation with the army. John says that "[the army] have a great deal of expertise that can be harnessed for archaeological work." I'm not sure about this attribute, but they do have lots of exciting stuff, which introduces questions concerning how individuals view the military on a personal level. There are lots of images of archaeologists in Iraq taking an obvious delight in the wearing of military dress and equipment (which they would plead is essential), and this behaviour chimes intriguingly with the adoption of military gear on sites in the UK, from the entrenching tools and gas-mask bags of the 1950s and 1960s, to the combat trousers and camouflage gear of the 21st century. At one point John lovingly names his transport (not just a helicopter but a Merlin helicopter), and lists the team (not a first aider, but a medic; not just a camera team, but a combat camera team) with a care bordering on fetishism.

Our relationship with the army is complex; however, the army is not separate from our society, but part of it. We must develop a sophisticated response to the question of how we interact with it, in the same way as we do for any aspect of our complex society.

\section{References}

Apocalypse Now. dir. Francis Ford Coppola (United Artists, 1979).

UNESCO, 1954. Convention for the Protection of Cultural Property in the Event of Armed Conflict. [http://www.icomos. org/hague/] [Accessed 13 June 2009]. 